\title{
Neuropsychotoxicity of Abused Drugs: Effects of Serotonin Receptor Ligands on Methamphetamine- and Cocaine-Induced Behavioral Sensitization in Mice
}

\author{
Yukio Ago ${ }^{1}$, Shigeo Nakamura ${ }^{1}$, Akemichi $\mathrm{Baba}^{2}$, and Toshio Matsuda ${ }^{1,3, *}$ \\ ${ }^{1}$ Laboratory of Medicinal Pharmacology, Graduate School of Pharmaceutical Sciences, Osaka University, \\ 1-6 Yamada-oka, Suita, Osaka 565-0871, Japan \\ ${ }^{2}$ Laboratory of Molecular Neuropharmacology, Graduate School of Pharmaceutical Sciences, Osaka University, \\ 1-6 Yamada-oka, Suita, Osaka 565-0871, Japan \\ ${ }^{3}$ Department of Experimental Disease Model, The Osaka-Hamamatsu Joint Research Center For Child Mental Development, \\ Graduate School of Medicine, Osaka University, 2-2 Yamada-oka, Suita, Osaka 565-0871, Japan
}

Received September 7, 2007; Accepted October 4, 2007

\begin{abstract}
Repeated administration of psychostimulants elicits a progressive enhancement of locomotor activity known as behavioral sensitization. Central dopamine (DA) neurons play key roles as the neural substrates mediating behavioral sensitization, but the role of the serotonin (5HT) system in the sensitization is not fully elucidated. We have recently demonstrated that osemozotan, a specific 5- $\mathrm{HT}_{1 \mathrm{~A}}-$ receptor agonist, and ritanserin, a 5- $\mathrm{HT}_{2}$-receptor antagonist, inhibited the expression and development of both methamphetamine- and cocaine-induced behavioral sensitization in mice and that these drugs attenuated the maintenance of behavioral sensitization of methamphetamine, but not that of cocaine. We also found that azasetron, a 5$\mathrm{HT}_{3}-$ receptor antagonist, inhibited the expression and development of the sensitization induced by methamphetamine and cocaine, respectively. Neurochemical studies using a microdialysis technique showed that repeated methamphetamine enhanced the methamphetamine-induced increase in 5-HT release in the prefrontal cortex. The sensitization of 5-HT release in methamphetamine-treated mice was attenuated by osemozotan and ritanserin. These findings suggest that the 5-HT system plays an important role in methamphetamine- and cocaine-induced behavioral sensitization in mice and imply that $5-\mathrm{HT}_{1 \mathrm{~A}}-$ receptor agonists and 5- $\mathrm{HT}_{2}-$ receptor antagonists may have a potential therapeutic value for the treatment of methamphetamine abuse or psychosis.
\end{abstract}

Keywords: drugs of abuse, behavioral sensitization, methamphetamine, cocaine, serotonin (5-HT)-receptor ligand

\section{Introduction}

Amphetamine, methamphetamine, and cocaine are the central nervous system stimulants, and its prolonged use results in addiction and psychosis that is indistinguishable from paranoid type schizophrenia (1). Repeated administration of these psychostimulants can enhance the stimulating effect on locomotor activity, a phenomenon called behavioral sensitization. This

*Corresponding author. matsuda@phs.osaka-u.ac.jp

Published online in J-STAGE: January 16, 2008

doi: 10.1254/jphs.FM0070121 behavioral model has been used to analyze the neural modification associated with repeated psychostimulants exposure and withdrawal (2). The mesocorticolimbic dopamine (DA) system plays a crucial role $(3-5)$, but several lines of evidence have clearly demonstrated that DA is not the sole mediator of the behavioral effects of psychostimulant drugs. The occupation of the DA transporter by selective DA reuptake blockers does not correlate with their locomotor stimulant effects $(6,7)$. In addition, the expression of psychostimulant-induced locomotor sensitization can be dissociated from the expression of the sensitization of the DA response in the nucleus accumbens $(8,9)$, striatum $(10,11)$ and 
prefrontal cortex (12). Since psychostimulants do not only interact with the DA reuptake site, but also with the serotonin (5-HT) reuptake site, it is possible that the increased levels of extracellular 5-HT may participate in psychostimulant-induced behavioral sensitization. This increased 5-HT interacts with 5-HT receptors, so that 5-HT receptors may be important targets for pharmacological interventions. To date, at least 14 different 5-HT receptors have been characterized (13). Particularly, $5-\mathrm{HT}_{1 \mathrm{~A}}, 5-\mathrm{HT}_{1 \mathrm{~B}}, 5-\mathrm{HT}_{2 \mathrm{~A}}, 5-\mathrm{HT}_{2 \mathrm{C}}, 5-\mathrm{HT}_{3}$, and 5- $\mathrm{HT}_{6}$ receptors are more abundant in mesolimbic regions including the ventral tegmental area and terminates in several forebrain structures that regulate drug craving, emotion, and reward. We have recently examined the effects of the 5- $\mathrm{HT}_{1 \mathrm{~A}}-$ receptor agonist osemozotan (14), the 5- $\mathrm{HT}_{2}-$ receptor antagonist ritanserin (15), and the 5$\mathrm{HT}_{3}$-receptor antagonist azasetron (16) on methamphetamine- and cocaine-induced behavioral sensitization in mice $(17-19)$. This mini-review summarizes the effects of these 5-HT-receptor ligands on methamphetamineand cocaine-induced behavioral sensitization in mice and the possible role of the prefrontal 5-HT system in the sensitization.

\section{Methamphetamine-induced behavioral sensitization in mice}

There are accumulating evidences that acute amphetamine or methamphetamine-induced hyperlocomotion is modulated by $5-\mathrm{HT}_{1 \mathrm{~A}}-, 5-\mathrm{HT}_{1 \mathrm{~B}^{-}}, 5-\mathrm{HT}_{2 \mathrm{~A}}-, 5-\mathrm{HT}_{2 \mathrm{C}^{-}}, 5-$ $\mathrm{HT}_{3}-$, 5- $\mathrm{HT}_{6}-$, and 5- $\mathrm{HT}_{7}-$ receptor agonists and/or antagonists, while, the roles of 5-HT receptors in the sensitization are not fully elucidated. Przegaliñski et al. $(20,21)$ reported that a $5-\mathrm{HT}_{1 \mathrm{~A}}-$ receptor agonist, $8-\mathrm{OH}-$ DPAT, inhibited the expression and development of amphetamine-induced sensitization in mice and that a 5- $\mathrm{HT}_{1 \mathrm{~B}}-$ receptor antagonist, SB 216641, inhibited the development, but not the expression, of amphetamineinduced sensitization in mice. Tanaka et al. (22) reported that ritanserin partially inhibited the development of methamphetamine-induced behavioral sensitization in rats, and Auclair et al. (23) reported that a 5- $\mathrm{HT}_{2 \mathrm{~A}}$ receptor antagonist inhibited the development of amphetamine-induced behavioral sensitization in mice. Furthermore, Yoo et al. (24) have shown that ondansetron, a 5- $\mathrm{HT}_{3}-$ receptor antagonist, attenuated the expression and development of methamphetamineinduced behavioral sensitization. However, there are no studies demonstrating whether the 5-HT-receptor ligands improve the behavioral sensitization when administered after establishment of the sensitization. This point appears to be the most important, in view of treatment for drug abuse. Then, we examined the effects of osemozotan, ritanserin, and azasetron on the development, expression, and maintenance of methamphetamine-induced behavioral sensitization in mice (Table 1). Repeated administration of methamphetamine $(1 \mathrm{mg} / \mathrm{kg})$ for 7 days enhanced methamphetamine challenge-induced locomotor activity, and this sensitization was observed even after its withdrawal for 7 14 days. Osemozotan and ritanserin, but not azasetron, inhibited the development of methamphetamine-induced locomotor sensitization in mice $(17,19)$. On the other hand, all these drugs significantly attenuated the expression of the sensitization. Interestingly, osemozotan and ritanserin, but not azasetron, also inhibited the maintenance of the sensitization, that is, these drugs reversed the established behavioral sensitization in mice. Furthermore, the inhibitory effect of osemozotan was antagonized by a low dose of WAY 100635 , the $5-\mathrm{HT}_{1 \mathrm{~A}}-$

Table 1. Summary of the effects of 5-HT-receptor ligands on methamphetamine- and cocaine-induced behavioral sensitization in mice

\begin{tabular}{llccc}
\hline Psychostimulant & Sensitization & Osemozotan & Ritanserin & Azasetron \\
\hline Methamphetamine & Development & $\downarrow$ & $\downarrow$ & - \\
& Expression & $\downarrow$ & $\downarrow$ & $\downarrow$ \\
Maintenance & $\downarrow$ & $\downarrow$ & - \\
& Development & $\downarrow$ & $\downarrow$ & $\downarrow$ \\
& Expression & $\downarrow$ & $\downarrow$ & - \\
& Maintenance & - & - & -
\end{tabular}

For the development of the sensitization, mice were coadministered drugs and psychostimulants repeatedly for 7 days and then challenged with psychostimulants after a 7-day withdrawal period (on day 15). For the expression of the sensitization, mice were administered psychostimulants repeatedly for 7 days and then challenged with psychostimulants after a 7-day withdrawal period (on day 15). Drugs were injected $30 \mathrm{~min}$ before its challenge dose of psychostimulants on day 15. For the maintenance of the sensitization, mice were treated with psychostimulants repeatedly for 7 days, administered drugs twice daily for 7 days, and challenged with psychostimulants after a 7 -day withdrawal period (on day 22 ). $\downarrow$ : inhibitory effect, 一: no effect. 
receptor antagonist. Since WAY100635 has a greater affinity for presynaptic 5-HT $\mathrm{HA}_{1 \mathrm{~A}}$ autoreceptors than for postsynaptic $5-\mathrm{HT}_{1 \mathrm{~A}}$ receptors $(25)$, it is possible that the effect of osemozotan may be due to the activation of presynaptic 5-HT $\mathrm{HT}_{1 \mathrm{~A}}$ receptors. Taken together, these findings suggest that $5-\mathrm{HT}_{1 \mathrm{~A}}-$ receptor agonists and 5$\mathrm{HT}_{2}$ receptor antagonists may have a therapeutic value for the treatment of methamphetamine abuse or psychosis.

\section{Cocaine-induced behavioral sensitization in mice}

Previous studies show that the 5- $\mathrm{HT}_{1 \mathrm{~A}}-(26,27), 5-$ $\mathrm{HT}_{1 \mathrm{~B}}-(28), 5-\mathrm{HT}_{2 \mathrm{~A}}-(29,30)$, and $5-\mathrm{HT}_{3}-(31-33)$ receptor antagonists inhibit cocaine-induced hyperlocomotion and behavioral sensitization, while the 5$\mathrm{HT}_{1 \mathrm{~A}^{-}}, 5-\mathrm{HT}_{1 \mathrm{~B}^{-}}$, and 5- $\mathrm{HT}_{2 \mathrm{~A}}-$ receptor agonists and 5$\mathrm{HT}_{2 \mathrm{C}}$-receptor antagonist enhance the locomotor stimulant effect of cocaine $(30,34,35)$. These results suggest that the central 5-HT system plays a role in cocaineinduced behavioral sensitization. However, all these studies were carried out in rats. Since there is a species difference pertaining to the behavioral effects that the 5 - $\mathrm{HT}_{1 \mathrm{~A}}-$ receptor agonist has on rats and mice $(36-39)$, the similar studies in mice appear to be important. Our recent results in mice are shown in Table 1 (18). Cocaine-induced hyperlocomotion was augmented by repeated administration of cocaine $(15 \mathrm{mg} / \mathrm{kg})$ to mice, and this sensitization persisted even after a 7-day withdrawal period. Under the condition, osemozotan and ritanserin inhibited the development and expression of cocaine-induced behavioral sensitization in mice. In addition, azasetron inhibited the development of cocaine-induced behavioral sensitization in mice. However, none of these ligands reversed cocaineinduced behavioral sensitization, when each drug was administered for 7 days after repeated cocaine administration. This finding suggests that the involvement of
5-HT system in the maintenance of behavioral sensitization is different between cocaine and methamphetamine in mice. The important findings are that the modulation of cocaine-induced sensitization by 5-HT-receptor ligands is observed in mice and that there is the species difference between rats and mice in the effect of the 5$\mathrm{HT}_{1 \mathrm{~A}}-$ receptor agonist on cocaine-induced behavioral sensitization.

\section{Neurochemical effects of repeated methamphet- amine administration}

The central DA system is well recognized to play an essential role in sensitization to psychostimulants for which the release and reuptake inhibition of DA are a primary mechanism mediating the motor behaviors (3). Most investigators have reported that an enhanced DA response in the nucleus accumbens (40), striatum (41, 42), and prefrontal cortex (43) may underlie behavioral sensitization, while some investigators have shown that behavioral sensitization can be obtained in the absence of an enhanced DA response in the DA projection regions $(8-12)$. The apparent discrepancy may be due to differences in the conditions for induction of behavioral sensitization such as stimulant treatment and period of drug withdrawal (44).

With regards to the effects of chronic methamphetamine administration on monoamine release, we have recently demonstrated that chronic methamphetamine enhanced methamphetamine challenge-induced increases in extracellular 5-HT levels in the prefrontal cortex, but did not affect methamphetamine challenge-induced increases in extracellular DA and noradrenaline levels (17) (Fig. 1). This enhanced 5-HT response is not observed in the striatum and nucleus accumbens. In this line, Salomon et al. (45) have reported that chronic $d$ amphetamine injections induced an increased reactivity of serotonergic neurons as measured by cortical extra-
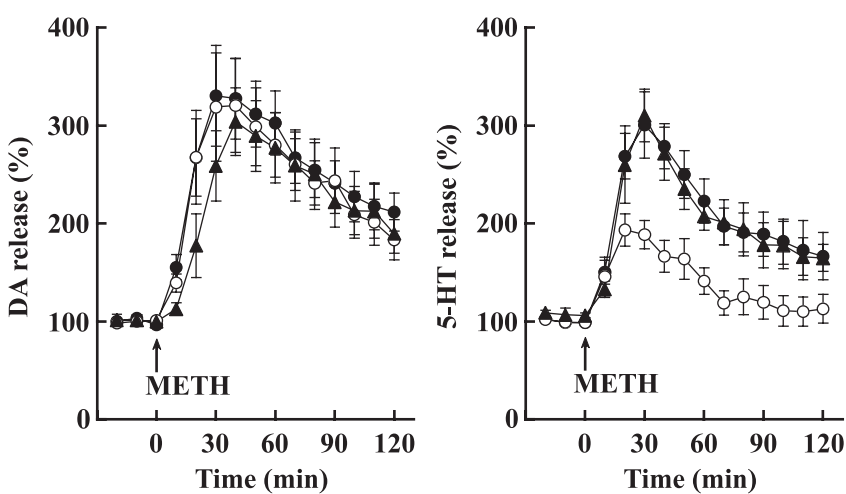

Fig. 1. Effects of single and repeated administration of methamphetamine (METH) on the in vivo release of DA, 5-HT, and noradrenaline (NA) in the prefrontal cortex of mice. Mice were administered saline or METH $(1 \mathrm{mg} / \mathrm{kg})$ repeatedly for 7 days. Saline-pretreated mice (open circles) and METH-pretreated mice withdrawn for 7 days (triangles) or 14 days (closed circles) from chronic METH administration were challenged with METH $(1 \mathrm{mg} / \mathrm{kg})$ at 0 time (arrow). Reproduced from ref. 17 with permission from Elsevier. 


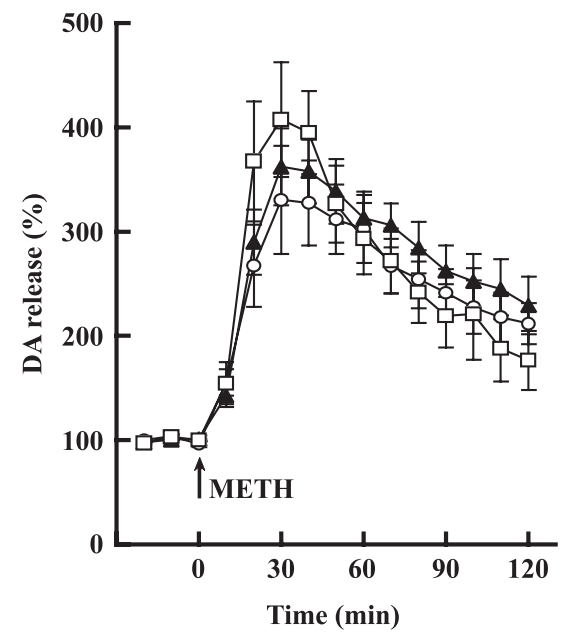

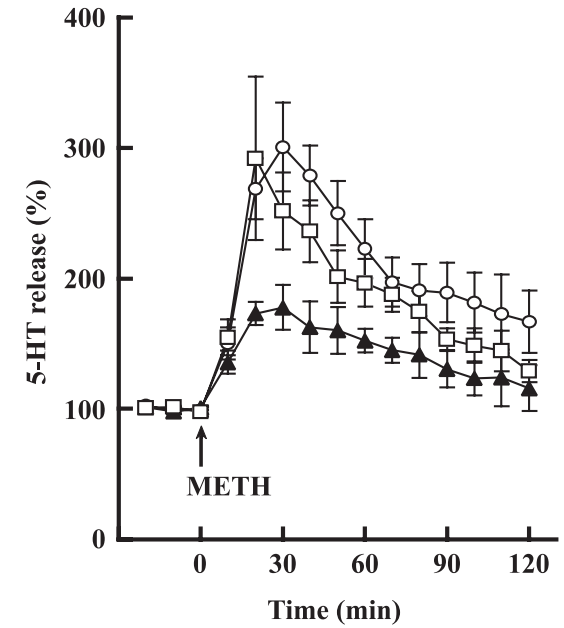

Fig. 2. Effects of osemozotan and WAY100635 during the maintenance phase on the methamphetamine (METH)-induced release of DA and 5-HT in the prefrontal cortex of mice. Mice were treated with METH $(1 \mathrm{mg} / \mathrm{kg})$ repeatedly for 7 days (days $1-7$ ), administered vehicle (circles) or osemozotan at $0.3 \mathrm{mg} / \mathrm{kg}$ (triangles) twice daily for 7 days (days $8-14$ ), and then challenged with METH $(1 \mathrm{mg} / \mathrm{kg})$ after a 7-day withdrawal period at $0 \mathrm{~min}$ (arrow) (on day 22). WAY100635 (0.1 mg/kg) was administered i.p. $30 \mathrm{~min}$ before osemozotan administration (squares). Reproduced from ref. 17 with permission from Elsevier.
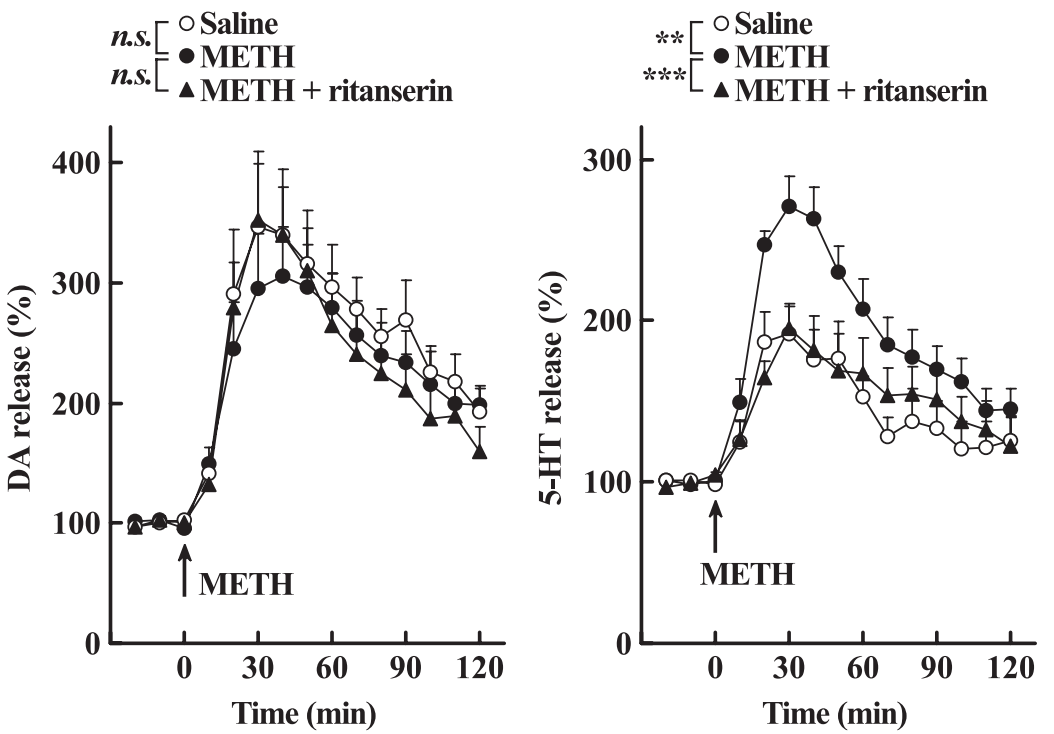

Fig. 3. Effect of ritanserin during the maintenance phase on the methamphetamine (METH)-induced release of DA and 5-HT in the prefrontal cortex of mice. Mice were treated with saline (open symbols) or METH $1 \mathrm{mg} / \mathrm{kg}$ (closed symbols) repeatedly for 7 days (days $1-7$ ), administered vehicle (circles) or ritanserin $3 \mathrm{mg} / \mathrm{kg}$ (triangles) twice daily for 7 days (days 8-14), and then challenged with METH $(1 \mathrm{mg} / \mathrm{kg})$ after a 7 -day withdrawal period at $0 \mathrm{~min}$ (arrow) (on day 22). $* * P<0.01, * * * P<0.001$. n.s.: not significant. Reproduced from ref. 19 with permission. cellular 5-HT levels after administration of $p$-chloroamphetamine, a 5-HT releaser. These findings suggest that the enhanced prefrontal 5-HT system is at least partly involved in psychostimulant-induced behavioral sensitization in mice.

\section{Effects of 5-HT-receptor ligands on methamphet- amine-induced changes in 5-HT and DA systems}

To study the role of the enhanced prefrontal 5-HT system in the maintenance of methamphetamineinduced behavioral sensitization, we examined the effects of osemozotan and ritanserin on the neuronal sensitization in the prefrontal cortex $(17,19)$. Both osemozotan and ritanserin significantly attenuated the enhanced 5-HT response in methamphetaminepretreated mice, but did not affect the methamphet- amine-induced increase in extracellular DA levels (Figs. 2 and 3). Furthermore, this effect of osemozotan was blocked by the coadministration of low doses of WAY100635 (Fig. 2). The finding suggests that osemozotan-induced reversal of methamphetamineinduced behavioral sensitization is related to an inhibition of serotonergic activity through the activation of presynaptic $5-\mathrm{HT}_{1 \mathrm{~A}}$ receptors. Regarding the effect of ritanserin, previous studies demonstrate that the activation of postsynaptic $5-\mathrm{HT}_{2 \mathrm{~A}}$ receptors in the prefrontal cortex stimulates the activity of the serotonergic system through changes in the activity of pyramidal neurons projecting to the dorsal raphe nucleus in rats and mice $(46,47)$. These reports suggest that $5-\mathrm{HT}_{2 \mathrm{~A}}$ receptors play roles in regulating the serotonergic activity in an opposite direction of $5-\mathrm{HT}_{1 \mathrm{~A}}$ autoreceptors. Thus, downand up-regulation of $5-\mathrm{HT}_{1 \mathrm{~A}}-$ and $5-\mathrm{HT}_{2 \mathrm{~A}}-$ receptor 


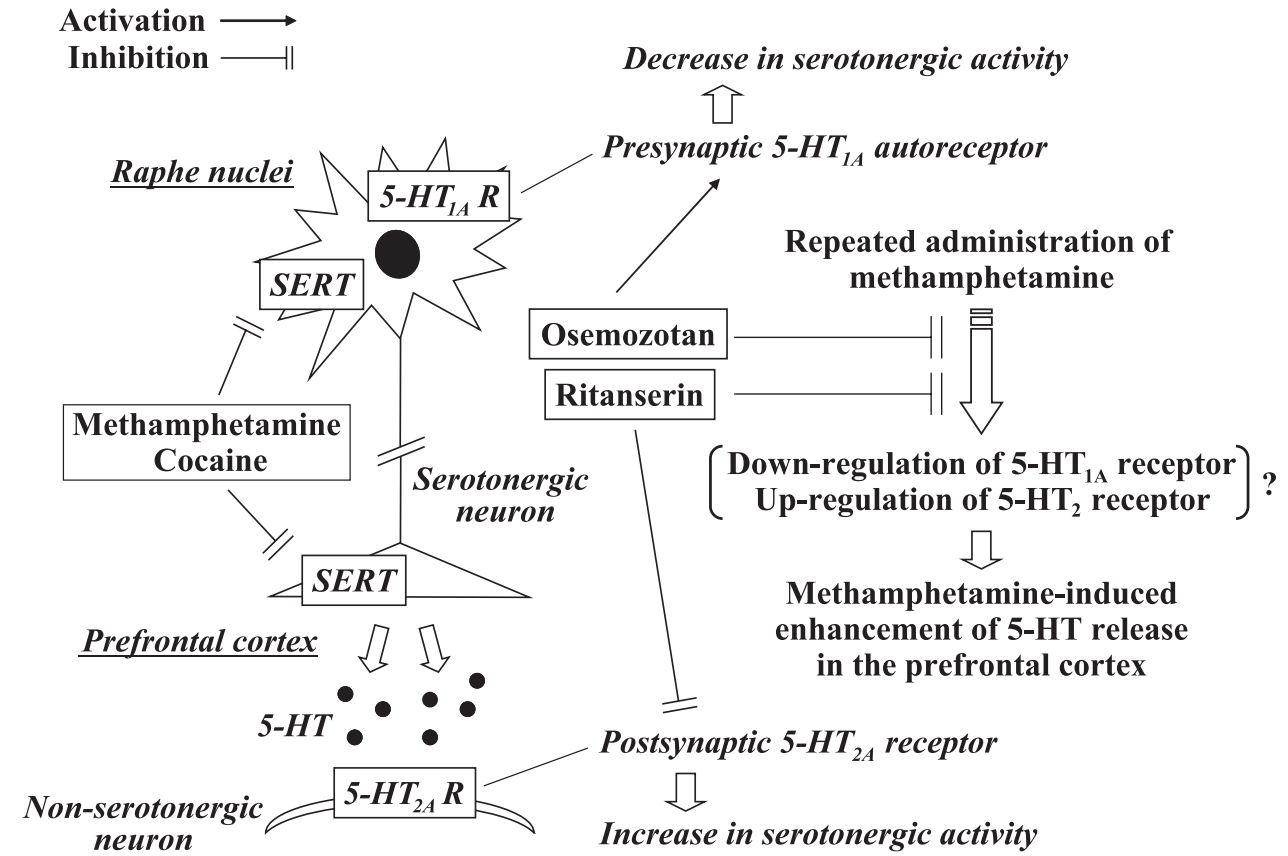

Fig. 4. Possible mechanisms for methamphetamine-induced neurochemical sensitization and the reversal effects of 5-HT-receptor ligands. SERT, serotonin transporter; $5-\mathrm{HT}_{1 \mathrm{~A}} \mathrm{R}, 5-\mathrm{HT}_{1 \mathrm{~A}}$ receptor; $5-\mathrm{HT}_{2 \mathrm{~A}} \mathrm{R}, 5-\mathrm{HT}_{2 \mathrm{~A}}$ receptor. function, respectively, may lead to methamphetamineinduced enhancement of 5-HT release in the prefrontal cortex, although the exact mechanism remains to be determined (Fig. 4). This idea may be in agreement with our findings that osemozotan and ritanserin attenuates the enhanced response of 5-HT release, although it is not known whether chronic methamphetamine affects the expression of 5- $\mathrm{HT}_{1 \mathrm{~A}}$ and $5-\mathrm{HT}_{2 \mathrm{~A}}$ receptors. Furthermore, we observed that osemozotan and ritanserin inhibited acute methamphetamine-induced hyperlocomotion in mice and that these drugs also inhibited acute methamphetamine-induced increase in the extracellular 5-HT, but not DA, levels in the prefrontal cortex. These findings suggest that the prefrontal 5-HT system may play a key role in the effects of osemozotan and ritanserin on methamphetamine-induced hyperactivity in mice.

\section{Concluding remarks}

The present review focused on the effects of 5-HTreceptor ligands on methamphetamine- and cocaineinduced behavioral sensitization and neurochemical changes in prefrontal 5-HT and DA systems in mice. Although neuronal control of locomotor activity is more likely to be associated with neurochemical changes in the nucleus accumbens and striatum than in the prefrontal cortex, our findings suggest that the 5-HT system, including $5-\mathrm{HT}_{1 \mathrm{~A}}$ and $5-\mathrm{HT}_{2}$ receptors, is involved at least partly in methamphetamine-induced behavioral effects such as sensitization and the locomotor stimulant effect in mice. In contrast, the 5HT-related mechanisms underlying cocaine-induced behavioral sensitization remains to be determined because osemozotan, ritanserin, and azasetron did not affect the maintenance of the sensitization. Since the establishment and expression of sensitization is part of psychostimulant addiction and psychosis, these studies imply that $5-\mathrm{HT}_{1 \mathrm{~A}}-$ receptor agonists and $5-\mathrm{HT}_{2}-$ receptor antagonists may have a potential therapeutic value for the treatment of methamphetamine abuse or psychosis.

\section{Acknowledgment}

This work was supported by grants form the Ministry of Education, Science, Sports, and Culture of Japan and Mitsubishi Pharma Co.

\section{References}

1 Pierce RC, Kalivas PW. A circuitry model of the expression of behavioral sensitization to amphetamine-like psychostimulants. Brain Res Rev. 1997;25:192-216.

2 White FJ, Kalivas PW. Neuroadaptations involved in amphetamine and cocaine addiction. Drug Alcohol Depend. 1998;51:141-153.

3 Nestler EJ. Molecular basis of long-term plasticity underlying addiction. Nature Rev Neurosci. 2001;2:119-128.

4 Vanderschuren LJ, Kalivas PW. Alterations in dopaminergic and glutamatergic transmission in the induction and expression of behavioral sensitization: a critical review of preclinical studies. Psychopharmacology. 2000;151:99-120.

5 Wise RA. Brain reward circuitry: insights from unsensed 
incentives. Neuron. 2002;36:229-240.

6 Rothman RB, Grieg N, Kim A, De CB, Rice KC, Carroll FI, et al. Cocaine and GBR12909 produce equivalent motoric responses at different occupancy of the dopamine transporter. Pharmacol Biochem Behav. 1992;43:1135-1142.

7 Newman AH, Allen AC, Izenwasser S, Katz JL. Novel $3 \alpha-$ (diphenylmethoxy)tropane analogs: potent dopamine uptake inhibitors without cocaine-like behavioral profiles. J Med Chem. 1994;37:2258-2261.

8 Szumlinski KK, McCafferty CA, Maisonneuve IM, Glick SD. Interactions between 18-methoxycoronasidine (18-MC) and cocaine: dissociation of behavioural and neurochemical sensitization. Brain Res. 2000;871:245-258.

9 Kuczenski R, Segal DS, Todd PK. Behavioral sensitization and extracellular dopamine responses to amphetamine after various treatments. Psychopharmacology. 1997;134:221-229.

10 Segal DS, Kuczenski R. In vivo microdialysis reveals a diminished amphetamine-induced DA response corresponding to behavioral sensitization produced by repeated amphetamine pretreatment. Brain Res. 1992;571:330-337.

11 Iyo M, Bi Y, Hashimoto K, Inada T, Fukui S. Prevention of methamphetamine-induced behavioral sensitization in rats by a cyclic AMP phosphodiesterase inhibitor, rolipram. Eur J Pharmacol. 1996;312:163-170.

12 Hamamura T, Fibiger HC. Enhanced stress-induced dopamine release in the prefrontal cortex of amphetamine-sensitized rats. Eur J Pharmacol. 1993;237:65-71.

13 Barnes NM, Sharp T. A review of central 5-HT receptors and their function. Neuropharmacology. 1999;38:1083-1152.

14 Matsuda T, Yoshikawa T, Suzuki M, Asano S, Somboonthum P, Takuma K, et al. Novel benzodioxan derivative, 5-(3-[((2S)-1,4benzodioxan-2-ylmethyl)amino]propoxy)-1,3-benzodioxole $\mathrm{HCl}$ (MKC-242), with a highly potent and selective agonist activity at rat central serotonin ${ }_{1 \mathrm{~A}}$ receptors. Jpn J Pharmacol. 1995;69:357366.

15 Muntasir HA, Rashid M, Komiyama T, Kawakami J, Nagatomo T. Identification of amino acid residues important for sarpogrelate binding to the human 5-hydroxytryptamine ${ }_{2 \mathrm{~A}}$ serotonin receptor. J Pharmacol Sci. 2006;102:55-63.

16 Miyata K, Kamato T, Yamano M, Nishida A, Ito H, Katsuyama $\mathrm{Y}$, et al. Serotonin $(5-\mathrm{HT})_{3}$ receptor blocking activities of YM060, a novel 4,5,6,7-tetrahydrobenzimidazole derivative, and its enantiomer in anesthetized rats. J Pharmacol Exp Ther. 1991;259:815-819.

17 Ago Y, Nakamura S, Uda M, Kajii Y, Abe M, Baba A, et al. Attenuation by the $5-\mathrm{HT}_{1 \mathrm{~A}}$ receptor agonist osemozotan of the behavioral effects of single and repeated methamphetamine in mice. Neuropharmacology. 2006;51:914-922.

18 Ago Y, Nakamura S, Hayashi A, Itoh S, Baba A, Matsuda T. Effects of osemozotan, ritanserin and azasetron on cocaineinduced behavioral sensitization in mice. Pharmacol Biochem Behav. 2006;85:198-205.

19 Ago Y, Nakamura S, Kajita N, Uda M, Hashimoto H, Baba A, et al. Ritanserin reverses repeated methamphetamine-induced behavioral and neurochemical sensitization in mice. Synapse. 2007;61:757-763.

20 Przegaliñski E, Siwanowicz J, Baran L, Filip M. Activation of serotonin $(5-\mathrm{HT})_{1 \mathrm{~A}}$ receptors inhibits amphetamine sensitization in mice. Life Sci. 2000;66:1011-1019.

21 Przegaliñski E, Siwanowicz J, Nowak E, Papla I, Filip M. Role of $5-\mathrm{HT}_{1 \mathrm{~B}}$ receptors in the sensitization to amphetamine in mice. Eur J Pharmacol. 2001;422:91-99.

22 Tanaka T, Ishigooka J, Watanabe S, Nagata E, Miura S. Partial inhibition of reverse tolerance by a high dose of ritanserin or low dose of haloperidol in methamphetamine-sensitized rat. Jpn J Psychopharmcol. 1998;18:1-7.

23 Auclair A, Drouin C, Cotecchia S, Glowinski J, Tassin JP. 5$\mathrm{HT}_{2 \mathrm{~A}}$ and $\alpha \mathrm{lb}$-adrenergic receptors entirely mediate dopamine release, locomotor response and behavioral sensitization to opiates and psychostimulants. Eur J Neurosci. 2004;20:30733084.

24 Yoo JH, Cho JH, Yu HS, Lee KW, Lee BH, Jeong SM, et al. Involvement of $5-\mathrm{HT}_{3}$ receptors in the development and expression of methamphetamine-induced behavioral sensitization: 5- $\mathrm{HT}_{3 \mathrm{~A}}$ receptor channel and binding study. J Neurochem. 2006;99:976-988.

25 Ago Y, Koyama Y, Baba A, Matsuda T. Regulation by $5-\mathrm{HT}_{1 \mathrm{~A}}$ receptors of the in vivo release of 5-HT and DA in mouse frontal cortex. Neuropharmacology. 2003;45:1050-1056.

26 Müller CP, Carey RJ, De Souza Silva MA, Jocham G, Huston JP. Cocaine increases serotonergic activity in the hippocampus and nucleus accumbens in vivo: $5-\mathrm{HT}_{1 \mathrm{a}}$-receptor antagonism blocks behavioral but potentiates serotonergic activation. Synapse. 2002;45:67-77.

27 Müller CP, De Souza Silva MA, DePalma G, Tomaz C, Carey RJ, Huston JP. The selective serotonin ${ }_{1 \mathrm{~A}}$-receptor antagonist WAY 100635 blocks behavioral stimulating effects of cocaine but not ventral striatal dopamine increase. Behav Brain Res. 2002;134:337-346.

28 Przegaliñski E, Filip M, Papla I, Siwanowicz J. Effect of serotonin $(5-\mathrm{HT})_{1 \mathrm{~B}}$ receptor ligands on cocaine sensitization in rats. Behav Pharmacol. 2001;12:109-116.

29 Davidson C, Lazarus C, Xiong X, Lee TH, Ellinwood EH. 5- $\mathrm{HT}_{2}$ receptor antagonists given in the acute withdrawal from daily cocaine injections can reverse established sensitization. Eur J Pharmacol. 2002;453:255-263.

30 Filip M, Bubar MJ, Cunningham KA. Contribution of serotonin (5-hydroxytryptamine; 5-HT) 5- $\mathrm{HT}_{2}$ receptor subtypes to the hyperlocomotor effects of cocaine: acute and chronic pharmacological analyses. J Pharmacol Exp Ther. 2004;310: $1246-1254$

31 King GR, Xiong Z, Ellinwood EH Jr. Blockade of cocaine sensitization and tolerance by the co-administration of ondansetron, a 5- $\mathrm{HT}_{3}$ receptor antagonist, and cocaine. Psychopharmacology. 1997;130:159-165.

32 King GR, Xiong Z, Ellinwood EH Jr. Blockade of the expression of sensitization and tolerance by ondansetron, a $5-\mathrm{HT}_{3}$ receptor antagonist, administered during withdrawal from intermittent and continuous cocaine. Psychopharmacology. 1998;135:263269.

33 King GR, Xiong Z, Douglass S, Ellinwood EH. Long-term blockade of the expression of cocaine sensitization by ondansetron, 5- $\mathrm{HT}_{3}$ receptor antagonist. Eur J Pharmacol. 2000;394:97-101.

34 De La Garza R, Cunningham KA. The effects of the 5hydroxytryptamine $_{1 \mathrm{~A}}$ agonist 8-hydroxy-2(di- $n$-propylamino) tetralin on spontaneous activity, cocaine-induced hyperactivity and behavioral sensitization: a microanalysis of locomotor activity. J Pharmacol Exp Ther. 2000;292:610-617.

35 Szumlinski KK, Frys KA, Kalivas PW. Dissociable roles for 
the dorsal and median raphe in the facilitatory effect of $5-\mathrm{HT}_{1 \mathrm{~A}}$ receptor stimulation upon cocaine-induced locomotion and sensitization. Neuropsychopharmacology. 2004;29:1675-1687.

36 Blanchard RJ, Griebel G, Guardiola-Lemaitre B, Brush MM, Lee J, Blanchard DC. An ethopharmacological analysis of selective activation of $5-\mathrm{HT}_{1 \mathrm{~A}}$ receptors: the mouse $5-\mathrm{HT}_{1 \mathrm{~A}}$ syndrome. Pharmacol Biochem Behav. 1997;57:897-908.

37 Dulawa SC, Geyer MA. Effects of strain and serotonergic agents on prepulse inhibition and habituation in mice. Neuropharmacology. 2000;39:2170-2179.

38 Rigdon GC, Weatherspoon JK. 5-Hydroxytryptamine 1a receptor agonists block prepulse inhibition of acoustic startle reflex. J Pharmacol Exp Ther. 1992;263:486-493.

39 Sipes TA, Geyer MA. 8-OH-DPAT disruption of prepulse inhibition in rats: reversal with (+)WAY 100,135 and localization of site of action. Psychopharmacology. 1995;117:41-48.

40 Narita M, Akai H, Nagumo Y, Sunagawa N, Hasebe K, Nagase $\mathrm{H}$, et al. Implication of protein kinase $\mathrm{C}$ in the nucleus accumbens in the development of sensitization to methamphetamine in rats. Neuroscience. 2004;127:941-948.

41 Hamamura T, Akiyama K, Akimoto K, Kashihara K, Okumura $\mathrm{K}$, Ujike $\mathrm{H}$, et al. Co-administration of either a selective $\mathrm{D}_{1}$ or $\mathrm{D}_{2}$ dopamine antagonist with methamphetamine prevents methamphetamine-induced behavioral sensitization and neurochemical change, studied by in vivo intracerebral dialysis. Brain Res. 1991;546:40-46.
42 Shuto T, Kuroiwa M, Hamamura M, Yabuuchi K, Shimazoe T, Watanabe $\mathrm{S}$, et al. Reversal of methamphetamine-induced behavioral sensitization by repeated administration of a dopamine $D_{1}$ receptor agonist. Neuropharmacology. 2006;50: 991-997.

43 Stephans SE, Yamamoto BY. Effect of repeated methamphetamine administrations on dopamine and glutamate efflux in rat prefrontal cortex. Brain Res. 1995;700:99-106.

44 Paulson PE, Robinson TE. Amphetamine-induced timedependent sensitization of dopamine neurotransmission in the dorsal and ventral striatum: a microdialysis study in behaving rats. Synapse. 1995;19:56-65.

45 Salomon L, Lanteri C, Glowinski J, Tassin JP. Behavioral sensitization to amphetamine results from an uncoupling between noradrenergic and serotonergic neurons. Proc Natl Acad Sci U S A. 2006;103:7476-7481.

46 Bortolozzi A, Amargós-Bosch M, Adell A, Díaz-Mataix L, Serrats J, Pons S, et al. In vivo modulation of 5-hydroxytryptamine release in mouse prefrontal cortex by local $5-\mathrm{HT}_{2 \mathrm{~A}}$ receptors: Effect of antipsychotic drugs. Eur J Neurosci. 2003;18:1235-1246.

47 Martín-Ruiz R, Puig MV, Celada P, Shapiro DA, Roth BL, Mengod $G$, et al. Control of serotonergic function in medial prefrontal cortex by serotonin-2A receptors through a glutamatedependent mechanism. J Neurosci. 2001;21:9856-9866. 